\title{
Developing a Predictive Understanding of Landscape Importance to the Punan-Pelancau of East Kalimantan, Borneo
}

In order for local community views to be incorporated into new development initiatives, their perceptions need to be clearly understood and documented in a format that is readily accessible to planners and developers. The current study sought to develop a predictive understanding of how the Punan Pelancau community, living in a forested landscape in East Kalimantan, assigns importance to its surrounding landscapes and to present these perceptions in the form of maps. The approach entailed the iterative use of a combination of participatory community evaluation methods and more formal modeling and geographic information system techniques. Results suggest that landscape importance is largely dictated by potential benefits, such as inputs to production, health, and houses. Neither land types nor distance were good predictors of landscape importance. The gridcell method, developed as part of the study, appears to offer a simple technique to capture and present the knowledge of local communities, even where their relationship to the land is highly complex, as was the case for this particular community.

\section{INTRODUCTION}

Failure to effectively incorporate local views into the development process has long been recognized as a crucial constraint to the sustainability of conservation and development initiatives $(1,2)$. The need to capture local views has spawned the development of a variety of participatory tools that provide a means for outsiders to gain an understanding of local perceptions. Whereas the value of community sketch maps has long been recognized, it is only more recently that researchers have started to explore methods that combine participatory approaches with more formal geographic information system (GIS) technologies (3), thus giving rise to the emerging field of participatory geographic information systems (PGIS) (4). The documentation of local people's spatial knowledge in the form of georeferenced data and maps that can be readily combined and overlain with existing conventional map data provides a powerful tool for presenting and communicating local knowledge and perceptions and thereby promoting these in decisionmaking processes. Such techniques are being developed and used by various practitioners to address diverse goals. Examples include addressing land use conflicts in Ghana (5), safeguarding cultural heritage in Fiji (6), and monitoring urban slums in Ethiopia (7).

The species-rich tropical forests of East Kalimantan (Indonesian Borneo) form an essential component of the livelihoods for the sparsely settled local communities and are also recognized globally for their conservation importance (8). However, in the face of large, externally driven development projects such as commercial plantations, logging, and mining, together with rapid in-migration and growth of urban settlements, these forests are rapidly being modified, to the considerable detriment of local livelihoods and conservation goals.

A common perception of this region among distant planners (whether in government, business, or conservation) is of large forest areas empty of local significance and therefore offering opportunities waiting to be seized and exploited. In order for local communities to challenge and to influence decisions that are likely to have profound impacts on their livelihoods and thus avoid being further marginalized, there is an urgent need to understand and address their needs and aspirations and to communicate the local significance of these forests to decisionmakers $(9,10)$.

The primary purpose of this study was thus to develop practical map-based approaches to facilitate the incorporation of local views of the resident Punan Pelancau communities into the ongoing development process in the Malinau region of East Kalimantan. This entailed a process of investigating how the Punan Pelancau people view their surrounding landscape, developing a predictive understanding of their assignment of landscape importance, and presenting the results in the form of maps, to which planners and developers can readily relate.

The study builds directly on two previous research projects. The Centre for International Forestry Research (CIFOR) in partnership with various stakeholders was devising and testing methods to identify and understand local people's views and concerns regarding what is important regarding Malinau's landscapes and biodiversity. From this work we better understood the sites and resources that mattered to local people but we were frustrated by our inability to assess how accessibility influenced these values (11-13). For example, although we had developed maps of community territories showing key sites and resource areas we remained uncertain how values were spread across these maps and the underlying principles involved. We believed that such an understanding could help generalize and extrapolate results, might provide useful insights into what determines importance, and might lend themselves to generating GIS-based maps that could be a powerful means for communicating results to other stakeholders. The first two authors had experience in addressing such a spatial challenge in the drier savanna woodland environment in Mozambique (14-16). Lessons from the Mozambique research offered possible solutions to understanding landscape patterns. Our intention was to adapt and evaluate these methods in the context of Malinau's rugged and densely forested landscape. This work was undertaken within the context of CIFOR's broad objective of providing policy-relevant information that can enable more informed, productive, sustainable, and equitable decisions about the management and use of tropical forests (17).

\section{MATERIALS AND METHODS}

The upper Malinau basin comprises extremely steep and irregular terrain dominated by primary forest, with limited 


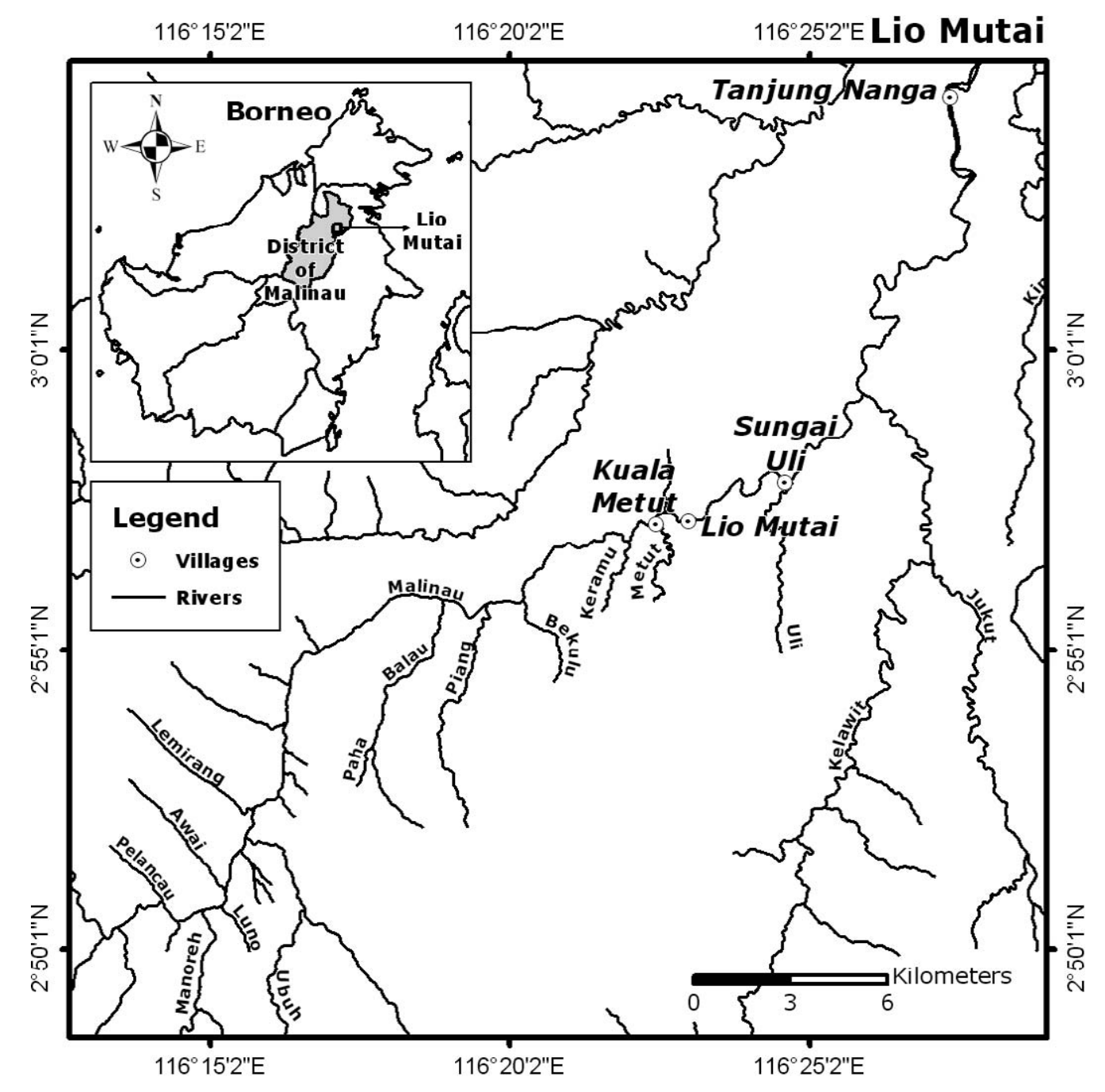

Figure 1. Map of the study area showing the location of Lio Mutai and neighboring villages.

occurrences of swidden fields and secondary forest (resulting from shifting cultivation) in association with small indigenous settlements. Altitude varies from about $100 \mathrm{~m}$ to more than 700 $\mathrm{m}$, mean annual rainfall is in the order of $4000 \mathrm{~mm}$, and mean daily temperatures are about $26-27^{\circ} \mathrm{C}(18)$. Soils are varied but inherently infertile, which combined with the prevalence of steep slopes, renders the area unattractive for the development of commercial plantation crops such as oil palm, pepper, cocoa, coffee, or rubber (19).

The forests contain valuable timber resources, but because of their remote location and the difficult terrain logging has previously been relatively restricted. However, this is beginning to change, largely because of the recent decentralization within Indonesia that has resulted in considerable upheavals in government control (20) together with the implementation of road building projects that are increasingly opening the area to loggers and other interests. The region supports a considerable wealth of additional plant and animal resources that are still being documented (21).

The area is very sparsely settled $\left(<1\right.$ inhabitant $\left.\mathrm{km}^{-2}\right)$, very difficult to access (by river, other than a single road constructed recently), and virtually undeveloped (e.g., there are no local schools or health facilities). Settlement is restricted to a number of small Punan villages. Formerly nomadic hunter-gatherers, most of the Punan now live in fixed settlements and are swidden cultivators, albeit with a relatively strong emphasis on extractive forest-based activities.

The Punan Pelancau, one of the several Punan lineages, were officially all relocated in the early 1980s to the downstream resettlement village of Long Loreh. Since then many have returned to live upstream where the primary livelihood activities remain hunting and gathering of forest products and small-scale subsistence agriculture. In February 2000, in addition to the Long Loreh community there were some 35 households in three upstream locations: Sungai Uli, Lio Mutai, and Metut (Fig. 1). Further upstream, toward the headwaters of the Malinau, the Punan Pelancau claim ownership of a territory covering some $500 \mathrm{~km}^{2}$, which although currently devoid of any permanent settlements is used for the gathering of forest resources. Eaglewood (22) collected from the forest is the principle source of cash income for these families. As in many other tropical forest regions, despite considerable research on a great variety of topics little is known about how local people view the landscape and how importance varies with location (11).

The investigation focused on the village areas of Lio Mutai, Metut, and the upstream tribal territory. Provisional maps of this region showing village locations, rivers, tributaries, and various sites and resource-rich areas had already been developed during previous work, drawing on satellite imagery, hand-held global positioning systems, and local knowledge and guidance (13).

During an initial field trip to Long Loreh, we worked with a group of Punan Pelancau informants who were familiar with the upstream area to identify livelihood activities, land types, and the goods and services associated with each land type. These were scored in terms of relative importance in respect to an average family achieving an adequate standard of living.

Drawing on experience in Mozambique (14), a simple cost/ benefit model was proposed whereby the importance value for any location was proportional to the weighted sum of all the 
goods and services to be found there (i.e., the benefits) divided by the distance from the village (representing the cost to access these resources). Distance, in this case, was a complex function, measured as the sum of the time taken to travel by boat, road, paths, and off paths, all converted to hours.

During a second field trip to Lio Mutai, field samples were taken to generate data to test the model. The resulting 113 sample points were selected to be at different distances from the village and to cover a variety of land types. Sampling was strongly constrained by the limited access and steep terrain, such that many parts of the tribal territory could not be reached. For each plot (roughly $25 \mathrm{~m}$ in radius) teams of villagers, including men and women, estimated levels of available resources and the distance to be traveled to get to the plot. The villagers would then consider how important the plot was to their well being and scored this using a scale of $1-$ 100 , where 1 was the least important site the villagers could conceive within the overall sample area and 100 was the most important. Additional exercises and discussion groups were convened to identify and clarify the nature of any specific locations of importance to the communities.

Various types of models and spatial analyses were investigated. The initial model was implemented as a Bayesian belief network (BBN) (23) as was employed in Mozambique (14). For each sample, the model would generate a predicted importance score given the particular values of goods and services recorded from the plot and the estimated distance from the village to the plot. A comparison of predicted scores against those given by the community (using Pearson's correlation) was disappointing, thus stimulating the testing of alternative modeling techniques.

Attention was then turned to general linear models (GLMs). Various models were developed using different combinations of goods and services. Models were developed with $80 \%$ of the field samples (constituting a core dataset) and then tested using the remaining 20\% (as independent samples). The predicted values for the independent dataset were compared against the actual scores given by the community using Pearson's correlation.

Standard GIS techniques were used to develop spatial representations or maps of model inputs and landscape importance scores and to perform comparisons between predicted and observed importance surfaces.

A third and simpler type of model was developed and tested in the field, which we called the grid-cell method. In this case, community members would indicate scores directly onto a map by placing different numbers of matchsticks into each grid square to indicate levels of different factors for that square. Three aspects were scored: the likelihood of finding resources in each cell (equivalent to benefits), the difficulty of procuring resources from the cell (equating to costs), and the frequency of visits to the cell to search for highly valued eaglewood (22). These scores were then tested by comparing the score for each cell against the mean score for all sample points falling within the cell.

\section{RESULTS}

\section{Livelihoods, Land Types, and Goods and Services}

The Punan Pelancau live in small villages on the banks of the Malinau river, in wooden houses built using timber from the adjacent forests. Roofs are constructed with either tin sheets or silat (palm leaves). Fields and fruit and vegetable gardens are cultivated in the surrounding areas. People keep livestock for consumption (chickens, ducks and pigs), hunting (dogs), and selling (chickens). Food resources harvested from the surrounding forests and rivers included wildlife (pigs, deer, monkeys), fish, wild fruits, and other plant foods. Other resources collected included firewood, eaglewood (for income), rattan (for crafts), medicines, and poisons.

The most important livelihood activities were said to be crop production, the collection of eaglewood, harvesting of wildlife and fish, and the making of crafts. Eaglewood was considered to be the most important source of income, but was restricted to about $50 \%$ of households. Concession fees, which accrued to all households, were identified as being the second most important source of income. Additional income was derived through selling rattan products ( $30 \%$ of households), chickens $(25 \%)$, fruit $(20 \%)$, and vegetables $(15 \%)$. Other important sources of income, but which were restricted to fewer households $(10 \%$ or less), included operating kiosks in the village, selling meat and fish, and renting boats.

In terms of land types as identified by the Punan informants, the landscape is dominated by primary forest, with smaller portions of mountain forest and logged forest. Other land types associated with settlements were villages, old abandoned village sites, fields and fallows, and concession camps. Additional aquatic-related types were big (deep navigable) rivers, small (non-navigable) rivers, depositional areas (sand or rock banks), islands, waterfalls, salt springs, and swamp forest. Logging roads and cemeteries were also considered to comprise specific geographical features.

The most important type, in terms of contribution to household well-being, was said to be intact forest, followed by big and small rivers, and fields (Table 1). The next most important types included village areas, old fields, concession camps, and logging roads. Other types were considered to be of relatively minor importance. Interestingly, logging was valued as a source of income, but the resulting logged areas were rated as being of much lower value than intact forest.

Commonly identified goods and services derived from the different land types were wildlife, rattan, eaglewood, crops, fields, vegetable and fruit gardens, building materials including silat leaves for roofing, sago, wild fruits, fish, and bamboo (Table 1). Intact forests supplied the greatest variety of goods and services (some 30 items out of a total basket of nearly 50), although other than timber most of these were also available from other land types. Only 15 goods and services were listed for logged forest. Certain resources and services were associated with specific land types. For example, river transport, fish, and turtles were specifically associated with rivers; crops were necessarily linked to fields, fruit, and vegetable gardens; villages were the primary location for houses (as opposed to temporary shelters), meetings, and livestock; logging operations provided concession fees, markets for goods, facilities, road transport, employment opportunities, and development assistance; river depositional areas provided resting places, sand, stones, and fishing bait; and view points were associated with mountain forest areas.

The principal constraints in terms of achieving access to resources were reported to be uncertainty regarding the finding of eaglewood, a lack of chainsaws, and poor crop yields. The overall listing was dominated by concerns relating to transport and equipment, which collectively accounted for $43 \%$ of the overall relative importance weighting (RIW). Difficulties in obtaining natural resources made up a further $36 \%$ of the RIW, whereas the remaining $22 \%$ was related to difficulties concerning the production of crops. To our surprise, distance was not identified as a constraint nor was there any mention of physical barriers or institutional limitations. However, the Punan Pelancau raised concerns during discussions that they did not have full rights to the areas where they were living, these being located within traditional territories seen as belonging to other Punan groups. They also saw a growing need to restrict access 


\begin{tabular}{|c|c|c|c|}
\hline Land type & $\mathbf{R I}$ & $\begin{array}{l}\text { Number of } \\
\text { resources }\end{array}$ & Principal kinds of resources \\
\hline Intact forest & 10 & 30 & $\begin{array}{l}\text { Eaglewood, timber, medicines, rattan, wildlife, wild fruit, sago, silat } \\
\text { leaf }\end{array}$ \\
\hline Big rivers & 7 & 22 & Fish/aquatic animals, transport, bamboo \\
\hline Small rivers & 7 & 21 & Fish/aquatic animals, paths, washing, bamboo \\
\hline Fields & 7 & 25 & Crops, wildlife \\
\hline Old fields & 5 & 16 & $\begin{array}{l}\text { Fields/gardens, firewood, wild fruit, building materials, rattan, } \\
\text { bamboo }\end{array}$ \\
\hline Villages & 4 & 14 & Houses, water, crops/gardens, livestock, meetings \\
\hline Logging concessions & 4 & 7 & $\begin{array}{l}\text { Concession fees, markets, employment, transport, development } \\
\text { assistance }\end{array}$ \\
\hline Logging roads & 4 & 13 & $\begin{array}{l}\text { Access to other places, markets, meetings, eaglewood, sago, silat } \\
\text { leaf }\end{array}$ \\
\hline Mountain forest & 3 & 9 & Eaglewood, wildlife, wild plant foods, rattan, sago, view points \\
\hline River depositional areas & 3 & 8 & Places for resting, firewood, fishing bait, sand, stones \\
\hline Old village sites & 2 & 7 & Fruit, rattan, wildlife \\
\hline Logged forest & 1 & 15 & $\begin{array}{l}\text { Fields/gardens, eaglewood, construction materials, wildlife, rattan, } \\
\text { plant foods, honey }\end{array}$ \\
\hline Swamp forest & 1 & 11 & Crops, rattan, fish/aquatic animals, medicines \\
\hline River islands & 1 & & \\
\hline Waterfalls & 1 & & \\
\hline Salt springs & 1 & 4 & Wildlife \\
\hline Cemeteries & 1 & 1 & Burial grounds \\
\hline
\end{tabular}

by outsiders, particularly non-Punan people, to their own traditional territory and the resources therein.

Community members identified a number of other locations of specific significance. These people have traditionally been highly mobile, such that there were a number of deserted old village sites, fruit groves, graves, and other sites of cultural significance in locations at considerable distance from current settlements. Various rules and regulations are traditionally associated with features like graves. It was difficult to discuss certain locations that were viewed as being associated with spirits. Although most individuals denied believing in these "old-fashioned ideas," it appeared that they did still have special significance. Because these sites were scattered in an unpredictable manner, no effort was made to include their "special values" in the predictive spatial models, although we do acknowledge their genuine significance and cultural importance for the community.

\section{Field Sample Scores}

Importance scores allocated to the 113 field samples varied from 4 to 100 , the median value being 45 points (Table 2). Although land types appeared to make an important contribution to the importance score for any location, statistically it was not possible to distinguish land types in terms of their importance scores. Even when the samples were scaled for their distance from Lio Mutai, the least important land type (logged forest) and the most important (fruit gardens) were distinguishable from the rest, but the others were indistinguishable.

\section{Models and Maps}

The initial BBN model took the form of benefits (the weighted sum of goods and services) divided by distance, the hypothesis being that importance would increase with higher levels of benefits and gradually decline with increasing distance from the village. Despite testing different combinations of resources and different distance functions (hours or kilometers), the degree of correspondence between expected and observed sample scores was low and never achieved better than $22 \%$.

A number of GLMs were developed and tested against the importance scores allocated in the field. The model judged to provide the most meaningful results (adjusted $\mathrm{r}^{2}=0.725$ ) included a group of goods on the benefit side related to production (fields, gardens, boat materials, rattan, and poisons) and to factors concerning health and home (medicines, houses, and drinking water). The cost side was represented by a distance time function. Comparison of the predicted scores for the 23 "independent" samples against their observed scores using Pearson's correlation yielded a correlation coefficient of 0.576 .

The grid-cell method was different from the other two modeling approaches in that it did not seek to understand the underlying processes so much as identify the importance scores assigned to a location. The results are therefore more descriptive

Table 2. Relative importance scores for sample plots from each land type.

\begin{tabular}{|c|c|c|c|c|}
\hline \multirow[b]{2}{*}{ Land type } & \multirow[b]{2}{*}{ No. of plots } & \multicolumn{3}{|c|}{ Relative importance } \\
\hline & & Range & Median & Mean \\
\hline Logged forest & 15 & $4-17$ & 15 & 14.67 \\
\hline Salt springs & 3 & $6-30$ & 15 & 17.00 \\
\hline River depositional areas & 7 & $15-65$ & 25 & 32.14 \\
\hline Small rivers & 4 & $5-55$ & 35 & 32.50 \\
\hline Intact forest & 42 & $6-76$ & 47 & 42.57 \\
\hline Old fields & 17 & $10-85$ & 60 & 56.53 \\
\hline Fields & 9 & $5-100$ & 60 & 59.78 \\
\hline Big rivers & 9 & $15-85$ & 68 & 60.33 \\
\hline Old village sites & 4 & $30-80$ & 66 & 60.75 \\
\hline Fruit gardens & 3 & $60-100$ & 85 & 81.67 \\
\hline Total & 113 & 4-100 & 45 & 43.67 \\
\hline
\end{tabular}




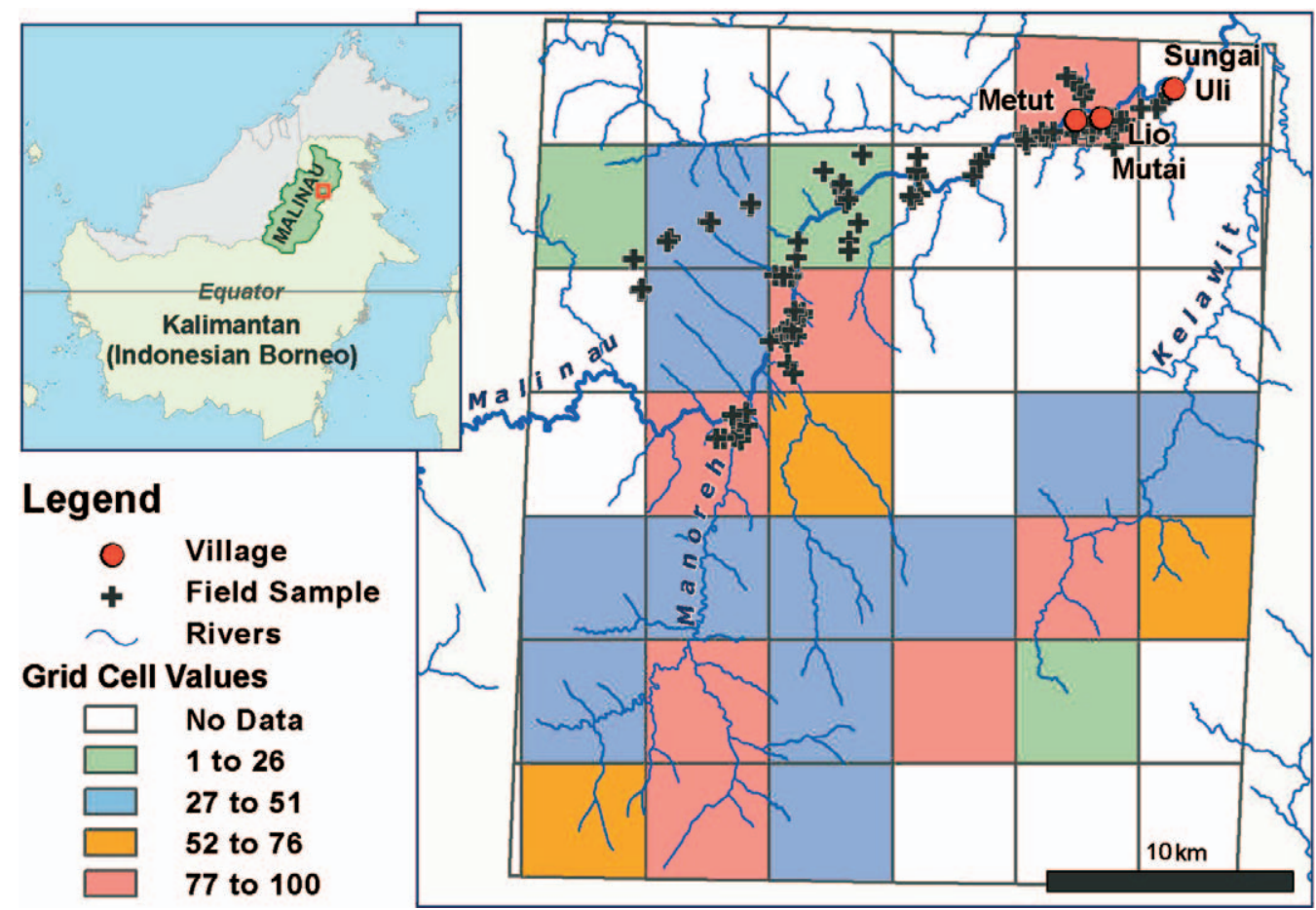

Figure 2. Map showing the grid-cell values indicating the likelihood of success in finding resources within each cell.

than explanatory. The conceptual cost benefit model was used to guide the exercise, with benefits being represented by the likelihood of successfully finding resources in a given grid square and costs by the degree of difficulty in accessing these resources. However, the predicted importance scores for each cell (i.e., success/difficulty) were less well correlated with the actual field scores than were the likelihood of success scores on their own $\left(\mathrm{r}^{2}=0.58\right.$ versus 0.73$)$.

High success or importance scores were indicated around the settlement areas of Lio Mutai and Metut and in the upstream territory around the junctions of the Mekayan and Menoreh rivers with the Malinau and in the upper catchments of the Kelawit and Menoreh rivers (Fig. 2). There was a negative relationship between mean importance score for all samples within a particular cell and the score given to that cell for degree of difficulty in obtaining resources, but the correlation was weak. The general pattern of difficulty in accessing resources was consistent with what might be expected, increasing with distance from Lio Mutai and from navigable rivers and roads.

Using GIS techniques, a spatial surface was generated of the field importance scores (Fig. 3). This shows why it was so difficult to develop importance models using either the BBN or GLMs. The original conceptual model was of a steady decline in importance with increasing distance from the settlements of Lio Mutai and Metut. The surface clearly shows that this is not true: there are several peaks of higher importance upstream of these villages that do not neatly fit into the general trend of declining importance with increasing distance. Although there was a general trend of declining importance with increasing distance, there were a number of other processes at work, which resulted in the complex landscape importance surface depicted in Figure 3.

\section{DISCUSSION}

The field results show that the Punan Pelancau have a much more complex relationship with their surrounding landscape than originally anticipated. In addition to there being a number of areas of settlement and importance to the community (Long Loreh, Lio Mutai, Metut, and the Pelancau territory) within the undisturbed upstream forest portion there are also peaks and troughs of importance at varying distances from the closest settlements of Lio Mutai and Metut. This explains why it was difficult to get satisfactory results from either the BBN or GLM approaches, in which costs were directly equated to distance from the village.

Results from the initial participatory exercises and the GLM and grid-cell models suggest that potential benefits (resources,

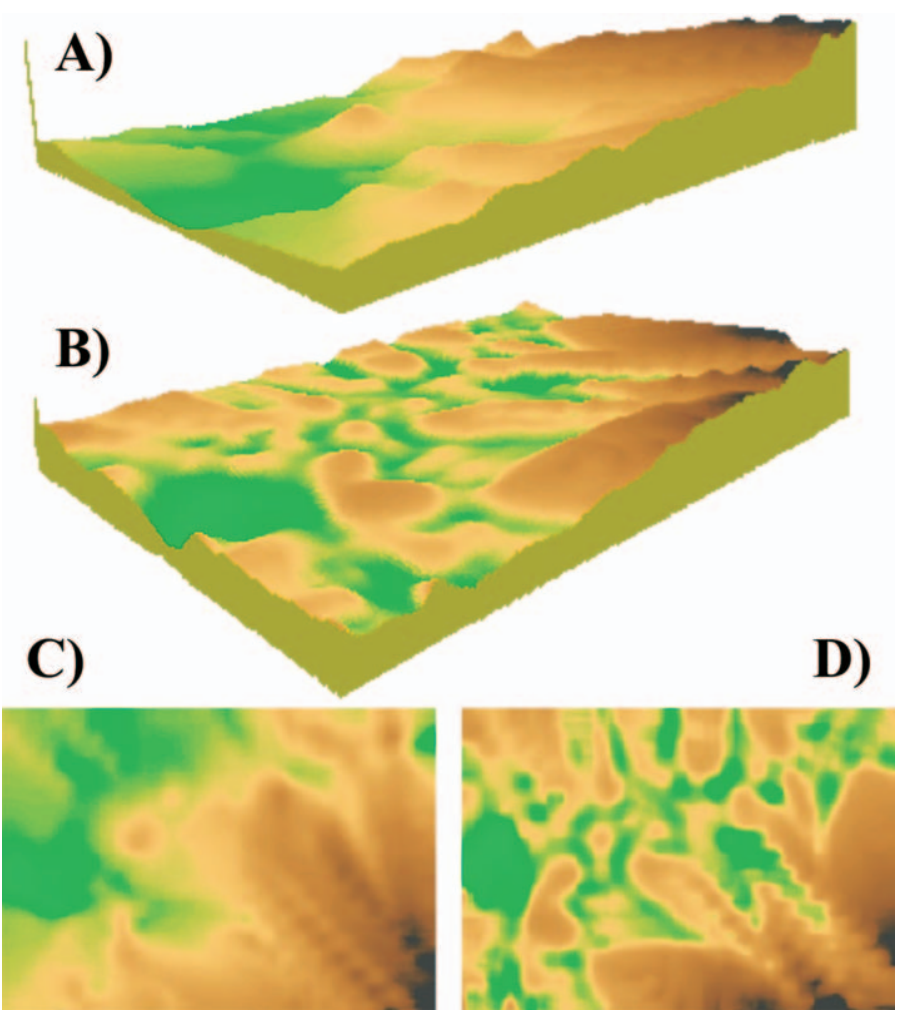

Figure 3. (a) Three-dimensional surface of the importance scores for field samples. Brown areas represent high scores and green areas lowest scores. (b) Three-dimensional surface of the standard error of the predicted importance scores (shading as for a). (c) Twodimensional representation of (a). (d) Two-dimensional representation of (b). 
goods, and services) make a stronger contribution to landscape importance than do cost factors in general and distance in particular. This is consistent with earlier findings from Mozambique, where data was gathered from two villages: one located centrally within and the other straddling the boundary of the Gorongosa National Park (14). Landscape values for both villages were strongly positively related to potential benefits. As expected, there was a negative relationship with cost factors (institutional barriers, physical barriers, dangers, and distance), but this was weak and not useful in predicting the ultimate value of any given location. Both sites were, however, relatively well endowed with natural resources such that most resources were extracted from within close proximity to each village, as was the case for the present study. As resources become less readily abundant, it is possible that cost factors, such as distance functions, may become more significant.

The lack of correlation between importance scores and the presence of eaglewood was surprising, given that this was identified as being the most important resource harvested from the upstream forest areas and was also rated as being the principal source of income. However, income did not appear to be a significant determinant of landscape importance. Nor were land types good predictors of importance scores. Importance scores within each land type tended to range from low to high, such that even when scaled for distance it was not possible to reliably distinguish between land types on the basis of importance scores.

The grid-cell method appears to have considerable potential as a simple tool to capture and represent community knowledge in the form of simple maps. The method is visible to community members, simple enough to be readily understood by everyone, and does not require any sophisticated analytical or modeling techniques. All grid cells are visible during the scoring process, such that the community members are working with an overview of the area. This should make it easier for participants to make the required abstract comparisons between different areas. The method has the additional benefit of covering the whole area, without having to visit everywhere on the ground. Interpretation and communication of the results is also straightforward. In this study the community was well prepared. They were already familiar with the base map: it had been produced with their involvement and they possessed copies in the village. Through this past work they were also very familiar with scoring exercises (24). Nonetheless, the grid-cell approach appears simple enough that if suitable base maps were produced and the methods were properly introduced other communities could probably do these evaluations themselves, thus providing a useful tool for local resource inventories.

Planners and developers should also find the grid-cell results, being in the form of geo-referenced two-dimensional maps, easy to understand and interpret and to combine with other spatial data (25). Thus, although not specifically tested here, the gridcell method does appear to provide a promising PGIS tool for the incorporation of local spatial knowledge into the development process.

The grid-cell method does, however, rely on the knowledge that participants have of the overall landscape. Communities less mobile than the Punan may have difficulties gauging the importance of more distant areas with which they are unfamiliar.

The grid-cell results are also more descriptive than explanatory. However, combined with questions and discussions, the results could be used to generate useful hypotheses as to the likely factors governing the assignment of importance scores. A potentially useful approach to understanding landscape importance in any given situation might be to start with the grid-cell method and then use these results to inform the application of more sophisticated modeling techniques, such as the Bayesian or general linear models investigated here.

More generally, the iterative approach adopted here of collecting data, posing hypotheses (models), testing them, and then using the results to further refine and improve the models appears to offer a particularly rewarding and beneficial approach to the understanding of landscape importance. Equally rewarding was that it entailed close interaction with community participants and thus provided a good opportunity for co-learning. In the context of development of the participating communities, the use of participatory co-learning approaches can be expected to deliver the best long-term results.

What are the implications for development planners? These results show that apparently empty forest areas, such as the upstream Pelancau tribal territory, can have unexpectedly high and complex importance to local communities. This has direct implications for potential developments within the region such as resettlement programs, logging, or implementation of large-scale commercial agriculture. Hopefully these results will contribute to a better understanding of such remote and marginalized local communities, help raise awareness of their needs, and thus lead to more balanced decisions concerning the management and use of forest resources within the wider region.

\section{References and Notes}

1. Chambers, R. 1983. Rural Development: Putting the Last First. Longman Scientific and Technical, Longman, UK.

2. Lynam, T., de Jong, W., Sheil, D., Kusumanto, Y. and Evans, K. 2007. A review of tools for incorporating community knowledge, preferences, and values into decision making in natural resources management. Ecology and Society 12. (http://www. in natural resources management.

3. Abbot, J., Chambers, R., Dunn, C., Harris, T., de Merode, E., Porter, G., Townsend, J. Abbot, J., Chambers, R., Dunn, C., Harris, T., de Merode, E., Porter, G., Townsend, J.
and Weiner, D. 1998. Participatory GIS: Opportunity or Oxymoron. Participatory Learning and Action Notes No. 33. International Institute for Environment and Development, London, UK, pp. 23-33.

4. IIED. 2006. Mapping for Change: Practice, Technologies and Communication. Participatory Learning and Action, No. 54. International Institute for Environment and Development, London, UK. $152 \mathrm{pp}$.

5. Kwaku Kyem, P.A. 2006. Finding common ground in land use conflicts using PGIS: lessons from Ghana. In: Mapping for Change: Practice, Technologies and Communication. Participatory Learning and Action, No. 54. International Institute for Environment and Development, London, UK. pp 36-40.

6. Rambaldi, G., Tuivanuavou, S., Namata, P., Vanualailai, P., Rupeni, S. and Rupeni, E. 2006. Resource use, development planning, and safeguarding intangible cultural heritage: lessons from Fiji Islands. In: Mapping for Change: Practice, Technologies and heritage: lessons from Fiji Islands. In: Mapping for Change: Practice, Technologies and
Communication. Participatory Learning and Action, No. 54. International Institute for Communication. Participatory Learning and Action, No. 54.
Environment and Development, London, UK. pp 28-35.

7. Lemma, T., Sliuzas, R. and Kuffer, M. 2006. A participatory approach to monitoring slum conditions: an example from Ethiopia. In: Mapping for Change: Practice, Technologies and Communication. Participatory Learning and Action, No. 54. International Institute for Environment and Development, London, UK. pp 58-66.

8. Sheil, D. 2002. Biodiversity research in Malinau. In: CIFOR. ITTO Project PD 12/97 Rev.1 (F): Forest, Science and Sustainability: The Bulungan Model Forest: Technical Report Phase 1, 1997-2001. Center for International for Forestry Research, and International Tropical Timber Organization, Bogor, Indonesia, pp. 57-107.

9. Colfer, C.J.P. and Resosudarmo, I.A.P. 2002. Which Way Forward? People, Forests and Policy Making in Indonesia. Resources for the Future, Washington, D.C.

10. Lynam, T.J.P., Cunliffe, R., Sheil, D., Wan, M., Salim, A., Priyadi, H. and Basuki, I. 2006. Livelihoods, Land Types and the Importance of Ecosystem Goods and Services. 2006. Livelihoods, Land Types and the Importance of Ecosystem Goods and Services.
Developing a Predictive Understanding of Landscape Valuation by the Punan Pelencau Developing a Predictive Understanding of Landscape Valuation by the Punan Pelencau
People of East Kalimantan. Center for International for Forestry Research, Bogor, People of East Kalimantan. Center for International for Forestry Research, Bogor,
Indonesia. Indonesia.

11. Pye-Smith, C. 2005. Biodiversity: a new perspective. New Scientist Magazine, 10 December 2005, 50-53.

12. Sheil, D. and Wunder, S. 2002. The value of tropical forest to local communities: complications, caveats and cautions. Cons. Ecol. 6. (http://www.consecol.org/vol6/iss2/ art9).

13. Sheil, D., Puri, R., Wan, M., Basuki, I., van Heist, M., Liswanti, N., Rukmiyati, Rachmatika, I. and Samsoedin, I. 2006. Local people's priorities for biodiversity: examples from the forests of Indonesian Borneo. Ambio. 35, 17-24.

14. Lynam, T., Cunliffe, R., Mapaure, I. and Bwerinofa, I. 2003. Assessment of the Value of Woodland Landscape Function to Local Communities in Gorongosa and Muanza Districts, Sofala Province, Mozambique. Center for International for Forestry Research, Bogor,

15. Lynam, T.J.P., Cunliffe, R.N. and Mapaure, I. 2004. Assessing the importance of
Ind 111 pp. woodland landscape locations for both local communities and conservation in Gorongosa and Muanza districts, Sofala province, Mozambique. Ecol. Soc. 9. (http:// www.ecologyandsociety.org/vol9/iss4/art1).

16. Lynam, T., Cunliffe, R., Reichelt, B., Owen, R., Sitoe, A. and Zolho, R. Human WellBeing and Ecosystem Services: An Assessment of Their Linkages in the GorongosaMarromeu Region of Sofala Province, Mozambique to 2015. Institute of Environmental Studies, University of Zimbabwe, $70 \mathrm{pp}$.

17. The Center for International Forestry Research (CIFOR) was established in 1993 as part of the Consultative Group on International Agricultural Research (CGIAR) in response to global concerns about the social, environmental, and economic consequences of forest loss and degradation. CIFOR research produces knowledge and methods to improve the well-being of forest-dependent people and to help countries manage their forests wisely well-being of forest-dependent people and to help countries manage their forests wisely
for sustainable benefits. This research is conducted in more than two dozen countries in collaboration with numerous partners. Since it was founded, CIFOR has also played a central role in influencing global and national forestry policies. 
18. CIFOR, Ministry of Forestry of Indonesia and ITTO. 2002. CIFOR-ITTO Project PD 12/97 Rev.1 (F): Forest, Science and Sustainability: The Bulungan Model Forest: Technical Report Phase I, 1997-2001. Center for International for Forestry Research and International Tropical Timber Organization, Bogor, Indonesia, $168 \mathrm{pp}$.

19. Basuki, I. and Sheil, D. 2005. Local Perspectives of Forest Landscapes: A Preliminary Evaluation of Land and Soils, and Their Importance in Malinau, East Kalimantan, Indonesia. Center for International for Forestry Research, Bogor. Indonesia, 114 pp.

. Barr, C. Wollenberg, E. Limberg G Anau, N Iwan, R Sudana, IM Meliono, Barr, C., Wollen and Djogo, T. Research, Bogor, Indonesia, $48 \mathrm{pp}$.

21. Sheil, D., Puri, R.K., Basuki, I., Van Heist, M., Wan, M., Liswanti, N., Rukmiyati, Sardjono, M.A., et al. 2003. Exploring Biological Diversity, Environment and Local People's perspectives in Forest Landscapes: Methods for a Multidisciplinary Landscape Assessment. Center for International Forestry Research, Bogor, Indonesia, 93 pp.

22. Eaglewood, or gaharu as it is known locally, is a high-value resinous product derived from fungus-infected trees in the genus Aquilaria.

23. Bayesian Belief Networks or BBNs are probabilistic models that use Bayesian probability theory in a network. Useful references to their use may be found in: Cain, J. 2001. Planning improvements in natural resources management. Guidelines for usin Bayesian networks to support the planning and management of development programmes in the water sector and beyond. Centre for Ecology and Hydrology (CEH) Wallingford, UK. and Jensen, F.V. 2001. Bayesian Networks and Decision Graphs. Springer.

24. Sheil, D and Liswanti, N. 2006. Scoring the importance of tropical forest landscapes with local people: patterns and insight. Environmental Management, 38, 126-136.

25. A map from the present work is included on one of the four explanatory posters based on this and related research activities that were developed (with community guidance to ensure accuracy and clarity) then mass produced and distributed in the region. Formal assessment reveals these posters have had a significant impact on the views and knowledge of various local stakeholders. Details are provided in Padmanaba, M. and Sheil, D. 2007. Finding and promoting a local conservation consensus in a globally important tropical forest landscape. Biodiversity and Conservation, 16, 137-151.

26. Many thanks to Agus Mohammad Salim who prepared Figures 1 and 3 for us. We thank all the community participants from Long Loreh, Lio Mutai, and Metut, without whom the study would not have been possible. We are also grateful to the many people who provided valuable support, both in CIFOR headquarters in Bogor and in the field, especially Ramses Iwan, Andy Darmawan, Miriam van Heist, and Lini Wollenberg. The research was funded by grants to CIFOR from the European Commission and the World Bank.

27. First submitted 12 September 2006. Accepted for publication 12 June 2007.
Robert N. Cunliffe is a freelance environmental consultant based in Harare, Zimbabwe. His current focus concerns the interface between communities and conservation, particularly with respect to protected area management within Southern Africa. His address: 4 Otilia Close, Avondale, Harare, Zimbabwe.

E-mail: rcunliffe@mango.zw

Timothy J. P. Lynam is a social and ecological systems scientist based at the Sustainable Ecosystems Division of CSIRO in Townsville, Australia. His current research activities focus on developing approaches and tools for the analysis and management of complex adaptive systems. His address: CSIRO, Sustainable Ecosystems, Davies Laboratory, University Road, Townsville, Queensland 4814, Australia.

E-mail: tim.lynam@csiro.au

Douglas Sheil is an ecologist with the Center for International Forestry Research in Indonesia. His current research interests include biological survey and monitoring methods, tree population ecology, and the interface between ecology, conservation and forestry. His address: Center for International Forestry Research (CIFOR), PO Box 6596 JKPWB, Jakarta 10065, Indonesia.

E-mail: d.sheil@cgiar.org

Meilinda Wan is an agronomist with the Center for International Forestry Research in Indonesia. Her main research interest is in biodiversity and people in changing landscapes. Her address: Center for International Forestry Research (CIFOR), PO Box
6596 JKPWB, Jakarta 10065, Indonesia.

E-mail: m.wan@cgiar.org

Agus Salim is a biostatistician currently working for the National Centre for Epidemiology and Population Health, Australian National University. His main research interest has been (and will always be) the interface between novel methodological development and good practice of statistics in medical and environmental sciences. His address: National Centre for Epidemiology and Population Health, Australian National University, Canberra ACT 0200 Australia.

E-mail: agus.salim@anu.edu.au

Imam Basuki is a soil specialist working with the Center for International Forestry Research in Indonesia. He has worked widely in Indonesia. He is interested in land evaluation and GIS. His address: Center for International Forestry Research (ClFOR), PO Box 6596 JKPWB, Jakarta 10065, Indonesia.

E-mail: i.basuki@cgiar.org

Hari Priyadi is a forest management specialist working with the Center for International Forestry Research in Indonesia. He has been involved in various research and surveys in Borneo and Sumatra. His main research interest is in biodiversity, forestry, and conservation. His address: Center for International Forestry Research (CIFOR), PO Box 6596 JKPWB, Jakarta 10065, Indonesia.

E-mail: h.priyadi@cgiar.org 